\title{
SELF-DEVELOPMENT AND MATURITY: \\ THE PSYCHOLOGICAL JOURNEY OF THREE BLACK \\ WOMEN CHARACTERS IN A RAISIN IN THE SUN
}

Kelly Cristina Torres de Barros Ferreira*

ABSTRACT :

This study aims at analyzing the psychological journey towards self-development and maturity of Mama, Ruth and Beneatha, the triangle of black women characters of A Raisin in the Sun. I argue here that each of these three female characters undergoes a process of personal growth in the play.

KEY WORDS: black women, race, gender.

Based on Carol Pearson's and Katherine Pope's definition of departure, initiation, and return as the three stages followed by a protagonist's journey towards growth, Elizabeth Brown-Guillory states, in Their Place On The Stage (1990), that the female characters of some black women playwrights as Hansberry "[...] undergo a personal and sometimes political odyssey or search for wholeness as they progress into six stages: koinonia, logos, metanoia, kerygma, didache, and eucharistia" (Guillory 1990: 81). After having gone through these six stages, facing the conflicts they found in "the world of chaos", the female characters are finally ready to face reality and not succumb to oppression.

The terms above are based on Koine, which is a variation or dialect of classical Greek, and adapted to the context of African-American culture and rituals. Koinonia means fellowship, and in the African-American context it gives the idea of blacks being "[...] united in something deeply, family, to be inextricably bound by common grounds or experiences [...]" (82). Logos is literally interpreted as "the word

* Mestre em Letras: Literaturas e Expressão da Alteridade (Área de concentração: Literaturas de Expressão Inglesa), 2004. 


\section{EMTESE}

Belo Horizonte, v. 9, p. I-28I, dez. 2005

of Jesus", but, in a broader sense, it can be defined as "[...] an awareness moment, a revelation that sets things in motion" (82). In the African-American experience it indicates the moment in which blacks are faced with their condition of racial oppression in the world, as though it were a moment when a "loss of innocence" occurred. Metanoia, the third stage, refers in Greek to a moment of conversion, a changing of mind. Kerygma is the following stage, the moment when the heroine is compelled to speak of her oppression; it is the "explosion" that can be either verbal or physical. The fifth stage is didache, which means teaching; in the African-American context it is the "[...] bottom line of a formal message that the heroine passes on to blacks", leaving a legacy to future generations. This message works as a catalyst for the last stage of personal growth. Eucharistia means gratitude, the moment of celebration; in the present context, it can be observed when a character finally finds peace and completeness. While Guillory proposes an analysis of Mama's six stages of personal growth, I am interested in discovering whether the other women characters of the play, Ruth and Beneatha, go through similar phases in their development. Thus, I propose to analyze each of these female characters separately, focusing on their own specificities to discover how or whether each one of them experiences a personal growth in the play.

Mama's journey into self-discovery and maturity can be considered crucial to the plot, because, through her pivotal role, she also points to her children the way of growth. As discussed in Their Place on the Stage, when Mama establishes with Ruth, her daughter-in-law, a relation of fellowship, by sharing with her some remarkable moments she spent with her husband, she steps into koinonia, the first stage of her internal journey (93). Mama recalls the difficulties she went through to raise her children, side by side with her husband Big Walter, who worked to death to provide a better life to their family after the loss of their son, little Claude, to poverty. By narrating her own experiences, Mama also encourages Ruth to continue with her daily struggle for survival, making her daughter-in-law muse on the value of life, since she was thinking of having an abortion.

The second stage in Mama's internal journey takes place when she realizes how she indirectly contributed to emasculate her son Walter Lee. This 
is her "loss of innocence" moment, in Guillory's definition of the six stages of selfdiscovery, the time when Mama's logos comes into being. Indeed, when Mama perceives that Walter Lee is profoundly disappointed at the non-realization of his dream of a liquor store business, she realizes she had never, until then, taken Walter seriously as an adult man capable of taking over a family and a business of his own. At this moment, Mama becomes aware of her dominant attitude towards her son, and decides to give him the money to start his new business. The only thing important for Mama at this moment is to empower her son with the role she had denied him during all those years, even if that meant the annihilation of her own dreams.

Her sense of guilt leads her into metanoia, the third stage of her personal growth. Following logos, this stage can be defined as the exact moment when Mama annihilates herself so that her son comes into being, assuming his role of head of the family: "And from now on any penny that come out of it or that go in it is for you to look after. For you to decide. It ain't much, but it's all I got in the world and I'm putting it in your hands" (Hansberry, 1959: 107).

The fourth stage is Mama's moment of anger, or kerygma, in which she "explodes" verbally and physically (she slaps her son in the face) after discovering that Walter had lost all the money of the family by handing it to Bobo, an unfair partner. At this time, Mama realizes that Big Walter's effort to give his family an opportunity to improve their lives was gone. The dream that she and her husband had had for years, of getting out of the ghetto, had dissipated in one single day.

Mama's entrance into didache, her fifth stage, starts when she recovers herself from the disappointment with Walter Lee. Later, after she had argued with her son, she comes to the conclusion that, sometimes, one has to give up his dreams and face reality. At this moment she seems to be resigned to the family's destiny of living in the ghetto, if that were the way things had to be.

Yet, when her son tells her he is willing to accept the white man's offer for them not to move into the white neighborhood, she embodies all the energy of her ancestors to teach Walter a lesson, to show him what it means to be a member of the Younger family:

MAMA. Son - I come from five generations of people who was slaves and sharecroppers - but ain't nobody in my family never let nobody pay 'em no money that was a way of telling us we wasn't fit to walk the earth. We ain't never been that poor. We ain't never been that - dead inside (143). 


\section{EMTESE}

Belo Horizonte, v. 9, p. I-28I, dez. 2005

Mama does all she can to show Walter that they are black, poor, and that they suffer discrimination, but that they should never give up their pride.

Finally, Mama's eucharistia brings her recovery of faith, after Walter Lee has courageously expelled the white man who offered them money not to move from their apartment. She finally achieves her completeness, and that is her moment of rejoicing, not just because they are going to move to a better home, but especially because she has managed to teach her children a lesson, pointing them the way to personal growth.

Ruth is Mama's daughter-in-law who is sometimes approached as the prototype role of a submissive black woman in the play. She is the woman character who has received less attention from the critics, who tend to see her within a very close stereotype. Ruth's path is also marked by a trajectory of personal development in the plot, but in her case it is not possible to describe the chronological sequence of the six stages proposed by Guillory. When Ruth finds out that she is pregnant, she starts a process of change that culminates in her maturity in the end of the play.

By analyzing Ruth's trajectory in the play, I notice that she has a moment of logos in the play, according to the definition proposed by Guillory. This moment is also related to the possibility of having an abortion, after she has realized how difficult it would be to raise another child under her condition as a poor black woman. Her logos, or "loss of innocence" moment, comes when she thinks about all the restrictions she would have to impose on her new child.

Ruth, therefore, takes her first step towards her objective, giving another woman a five-dollar down payment to have the abortion. The fact that Ruth is capable of deciding for an abortion is an indication that she is not the submissive wife she might appear to be. As she already has Travis, her 10 to 11 year-old boy, she is aware of the many things her son is deprived of; the boy does not have even a bedroom of his own. Thus, due to their poverty, Ruth being a maid and her husband a chauffer willing to leave his job and start a new business with people he does not know very we11, Ruth chooses to end her pregnancy, despite her religious upbringing. Thus, I notice that she is ready to break up with her family's values and religion, if that meant a more stable life. As Mama wants to persuade Ruth to change her mind, she tells walter the truth, believing her son will support his wife in that difficult moment. At first, her son does not believe his 
wife would be capable of having an abortion, but then comes Ruth's kerygma, "the heroine's compulsion to speak", and she emphatically tells him she would be able to do it.

WALTER. You don't know Ruth, Mama, if you think she would do that.

(Ruth opens the bedroom door and stands there a little limp)

RUTH. (Beaten) Yes I would too, Walter. (Pause) I gave her a five-dollar down payment (75).

In spite of Ruth's despair, Walter is completely shocked, and cannot utter a word of comfort to his wife.

When Ruth finally decides to cope with her oppression, she experiences a turning point, or metanoia, according to Guillory's definition. It is interesting to observe that, in Ruth's case, metanoia occurs after kerigma, the heroin's compulsion to speak. At this moment, she makes up her mind not to have the abortion, after having found in her husband the support needed to raise their children. After Walter's argument with Lindner, the representative of the white neighborhood that offers them money not to move, Ruth finally has enough reasons to be proud of her husband, who makes a beautiful defense of his family's values and traditions in the presence of their son, Travis.

The last moment in Ruth's personal development culminates with the accomplishment of her dream of moving from that "old rat trap", as she and Mama used to call the apartment where they lived. If we recall the beginning of the play, when the author gives the initial descriptions of Ruth, we perceive that she dreams of one day being known by her people as a settled woman. She shares Mama's dream of having a house with a yard, and, in the end, I notice how strong she has become, and how she is able to work hard not to let it fly away:

RUTH. Lena - I'11 work . . I'll work twenty hours a day in all the kitchens in Chicago ... I'll strap my baby on my back if I have to and scrub all the floors in America and wash all the sheets in America if I have to - but we got to MOVE! We got to get OUT OF HERE! (140).

Her completeness, or eucharistia, occurs when she starts to believe her dream does not need to be deferred forever, that there is still a big chance for it to come true. In the end of the play Ruth evolves towards what could be considered a more confident woman, although her personal development does not follow a sequential order, as does Mama's. 


\section{EM TESE}

Belo Horizonte, v. 9, p. I-28I, dez. 2005

Mama's daughter, Beneatha, is in her twenties and represents the prototype of a revolutionary girl in the play. Her name is Beneatha, but contrary to the preposition "beneath", which means "in or to a lower position than something, or directly under something"1, she does not allow herself to be subordinate to anything or anybody in the play, not even to her mother. While she aims at breaking with every idea that is imposed on her, without her personal choice, she is also in search for her identity, in an attempt to recover black people's traditions.

As Beneatha is the only member of the family who had the opportunity to go to university and be in touch with a variety of different ideologies and cultural backgrounds, she developed a more critical view of her condition as a poor black woman. The Nigerian student Joseph Asagai plays an important role in Beneatha's trajectory to personal development; in fact, he is the one who initiates her into koinonia, her first stage of growth. Beneatha's strong will to know more about Africa and the people from which she descends brings her closer to Asagai, who is African and, as she defined, "intellectual". In search for her black identity, Beneatha finds in Asagai a point of identification with her African roots. Her desire to belong to a group of people that share a common cultural background is the very essence of koinonia, the feeling of fellowship among one's own people.

There are two situations that stand out as Beneatha's logos, or "loss of innocence" moment. The first occurs when she is confronted with her dream of becoming a doctor. The fact that Beneatha is a black woman makes it harder for her to be accepted as a future professional in society. When her brother argues against her dream of becoming a doctor, he is amazed to see her engagement in achieving such a prestigious position. In Walter Lee's point of view, if a man like himself, in all his potentiality, is only able to get a job as a chauffer, how can his sister aspire to a higher position? He would certainly not be surprised if she got a job as a maid, the same as his wife's. For Walter, it is hard to accept women occupying higher positions, especially if they are black like him and his sister. He does not mince words to tell Beneatha his family is making many sacrifices to pay for her studies. Beneatha is 20 years old, and does not work as a maid like Mama and Ruth to support the family. Walter does not seem interested in his sister's future when he suggests that she should be a nurse instead: "Who the hell 
told you you had to be doctor? If you so crazy 'bout messing 'round with sick people then go be a nurse like other women - or just get married and be quiet ..." (38). Walter Lee, with all his chauvinism towards women's professional careers, believes women should aspire to secondary and more modest roles in society.

The other situation that is part of Beneatha's "loss of innocence" moment occurs when Asagai accuses her of being assimilated, when she engages in a superficial search for her black identity. Beneatha wants to look African, but her transformation is merely external, since she is worried about the use of Yoruba language and African costumes, although she wears a straight hair-do, similar to white women. For Asagai, she is a long way from her black identity, especially because she would still have to go beyond an external transformation and understand in depth her peculiar position as an African-American woman.

Beneatha hates it when Asagai accuses her of being an assimilationist, and, to avoid such comparison, she engages in a process of acculturation, trying to appropriate elements of African heritage in an attempt to rescue her roots. This moment corresponds to her third stage of growth, metanoia, when she decides to cope with the oppression around her, giving value to the beauty of her black African heritage, thereby changing her hair style and way of dressing.

Even while she attempted to preserve her African heritage, Beneatha could not deny that, given her condition as an African-American woman, she would be found in a peculiar position, as though located in the middle of a bridge, between African and American territories. She is so enthusiastic about descending from a people that have survived slavery and oppression that she decides to change her way of dressing to appear more conspicuously African. We do not know exactly up to what extent Beneatha is capable of giving up the white culture in favor of the African heritage. The crucial point for her is not to assimilate the white. In her point of view, to bring some elements of African heritage to her culture cannot be considered a practice of assimilation, but, rather, a form of acculturation.

Beneatha begins to enter her fifth stage of growth, didache, after she has become mature enough to face people as she is, and leaves a message for future generations, turning into a black woman committed to her gender and her 


\section{EM TESE}

Belo Horizonte, v. 9, p. I-28I, dez. 2005

race. Beneatha also discovers that her brother Walter had lost all the family's insurance money to an unfair partner. Being desperate at the thought of seeing her dream of studying medicine fall apart, she considers, for a moment, the possibility of abandoning everything, even her love for the mystery of curing sick people. Yet, Asagai, who is a sort of tutor in Beneatha's journey into maturity, persuades her once more to continue believing in and pursuing her dream. He shows Beneatha that she should not depend on her father's money to study medicine, and she should count on herself to reach her goals.

Finally, Beneatha finds out that, as an African-American woman, she is not simply African or American. When Asagai suggests that she abandon everything in America to go with him to Nigeria, she is no longer so confident that Africa would be the ideal place to live. When Beneatha comes to terms with the peculiar condition of what means to have an African-American heritage, she achieves her completeness or eucharistia, the last stage in her scale of personal development. This time, she celebrates not only her personal achievements, but also the accomplishments of her relatives, when she finally understands that the happiness of her family is also hers. Although she has the reasons to believe that her dream of becoming a doctor is "deferred" forever, since she can no longer count on her father's insurance money to pay for her studies, she learns that she can achieve happiness by being part of her family's dream and, at the same time, by never abandoning her most precious ideals. As Asagai has defined her, she is "Alaiyo", "One for Whom Bread - Food - Is Not enough" (65); thus, she would not settle for her condition as a black oppressed woman, and is willing to do all she can to overcome this double jeopardy.

The three women characters in Hansberry's play are not portrayed through stereotypes in which only good qualities are manifested. Mama is strong, dedicated to her family, but also very strict in her opinions, especially because she is a feverish follower of her people's traditions. Ruth is a docile mother and a dedicated wife, but she is also capable of deciding for an abortion, in spite of her conservative familiar background. Beneatha is revolutionary and dreams of changing the world, particularly her own country, but she is also egocentric and superficial in her process of acculturation by 
African roots. Thus, what is exactly the contribution of these women to their race and gender in the play? The only plausible answer I can provide for this question is: the fact that they are women and black, and that they believe they can generate life not only by giving birth to babies that will perpetuate their ethnic group, but also by nourishing dreams to be reborn forever in the minds of human beings.

NOTE:

1. According to the definition found in Longman Dictionary of Contemporary English (1995).

RESUMO:

Este estudo tem o objetivo de analisar a trajetória psicológica em busca do desenvolvimento pessoal de Mama, Ruth e Beneatha, o triângulo de personagens negras de A Raisin in the Sun. Meu argumento é de que cada uma dessas três mulheres vivencia um processo de crescimento pessoal na peça.

PALAVRAS-CHAVE: mulheres negras, raça e gênero.

\section{REFERENCES}

BROWN-GUILLORY, Elizabeth. Their Place on The Stage: Black Women Playwrights in America. New York: Praeger, 1990.

CARTER, Steven A. Hansberry's Drama. New York: Meridian, 1993.

HANSBERRY, Lorraine. A Raisin in the Sun. New York: Penguin, 1959. - To Be Young, Gifted and Black: Lorraine Hansberry in Her Own Words. Ed.

Robert Nemiroff. New York: New American Library, 1970. Longman Dictionary of Contemporary English. Harlow Essex, England: Longman, 1995.

WALKER, Alice. "In Search of Our Mother's Gardens." The Norton Anthology of Literature by Women. Ed. Sandra M. Gilbert and Susan Gubar. New York: Norton, 1985. 2366-74. 